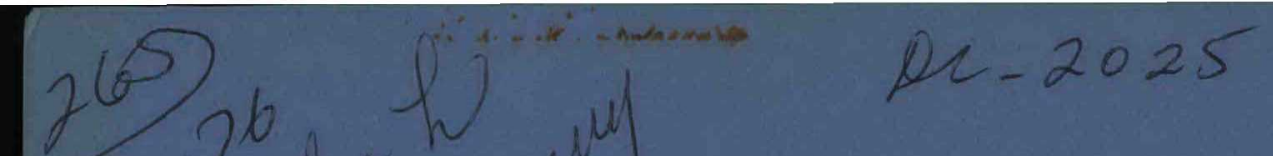

HEDL-TME 75-44

UC-79 b, h

AN EVALUATION OF THE EFFECTS OF

AN INTEGRAL FIN SPACER DESIGN

ON PREDICTED FUEL. PIN AND

SUBASSEMBLY DUCT PERFORMANCE
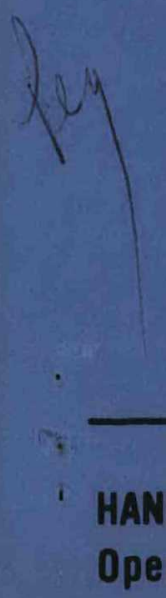

SUBASSEMBLY DUCT PERFORMANCE

' HANFORD ENGINEERING DEVELOPMENT LABORATORY

Operated by Westinghouse Hanford Company

Subsidiary of Westinghouse Electric Corporation

Prepared for the U.S. Energy Research and Development

Administration under Contract No. E(45-1)-2170

P.O. Box 1970 Richland, WA 99352 


\section{DISCLAIMER}

Portions of this document may be illegible in electronic image products. Images are produced from the best available original document. 

AN EVALUATION OF THE EFFECTS OF AN INTEGRAL FIN SPACER DESIGN ON PREDICTED FUEL PIN AND SUBASSEMBLY DUCT PERFORMANCE

W. H. Sutherland

D. A. Cantley

D. C. McCurry

M. B. Parker

January, 1976 Thus report was prepared as an account of work sponsored by the United States Government Neither the United States nor the Unuted Stutes Energy Resear $e$ and Developmert Adrutustation, nor any of subcontractors, or then employers contractors, warranty, express or 1 mpbed, ot assumes any leal abbitty or responsibility for the accuracy, completeness or usefulness of any informa tion, apparat us, product or process dasclosed, or represents that its use would not

\section{Hanford Engineering Development Laboratory}

Operated by the

Westinghouse

Hanford Company
A Subsidiary of

Westinghouse Electric Corporation for the United States

Energy Reseairch and

Development Administration Contract No. E(45-1)2170 
HEDL-TME 75-44

$U C-79 b, h$

\title{
AN EVALUATION OF THE EFFECTS OF AN INTEGRAL FIN SPACER DESIGN ON PREDICTED FUEL PIN AND SUBASSEMBLY DUCT PERFORMANCE
}

\author{
W. H. Sutherland \\ D. A. Cantley \\ D. C. McCurry \\ M. B. Parker \\ January, 1976
}

\begin{abstract}
The effect of an integrally finned fuel pin cladding design on LMFBR subassembly performance has been evaluated. Effects on thermal/hydraulics, fuel pin lifetime and duct iifetime are considered. Results are presented for 19, 61 and 217 pin subassemblies.
\end{abstract}




\section{CONTENTS}

Page

I. SUMMARY 1

II. INTRODUCTION 2

III. DISCUSSION OF ANALYSIS AND SUMMARY OF RESULTS 2

A. THERMAL/HYDRAULIC ANALYSIS 3

B. FUEL PIN STRUCTURAL ANALYSIS

C. SUBASSEMBLY DUCT STRUCTURAL ANALYSIS 23

IV. CONCLUSIONS AND RECOMMENDATIONS 25

REFERENCES 28 


\section{TABLES}

Table

Page

I. Comparison of Thermal/Hydraulic Performance for 19 Pin Subassemblies Utilizing Wire Wrap Spacers and Integral Fin Spacers

II. Comparison of Thermal/Hydraulic Performance for 61 Pin Subassemblies Utilizing Wire Wrap Spacers and Integral Fin Spacers

III. Comparison of Thermal/Hydraulic Performance for 217 Pin Subassemblies Utilizing Wire Wrap Spacers and Integral Fin Spacers

IV. Fuel Cladding Geometric Configurations

V. Environmental Conditions for Steady State Thermal and Elastic Stress Analyses

VI. Environmental Conditions for Creep Analyses

VII. CW 316 Stainless Steel Properties Used in Analyses

VIII. Maximum Temperatures and Effective Stresses of Axially Finned Models (Case 1 Through Case 5)

IX. Maximum Effective Stress and Maximum Total Creep Strain (Cylindrical Tube and Tube Region of Case 2) 


\section{FIGURES}

\section{Figure}

Page

1. Axially Finned Fuel Cladding Cross-Section

2. Boundary Conditions of Axially Finned Cladding Models and the Cylindrical Tube

3. Geometric Configurations of Axially Finned Cladding Models and the Cylindrical Tube

4. Steady State Temperature Distribution (Case 1: Axial Location $=8.25$ in.)

5. Effective Stress Contour Plots: Thermal Load (Case 1: Axial Location $=8.25$ in.)

6. Effective Stress Contour Plots: Pressure Load (Case 1: Axial Location $=8.25$ in.)

7. Typical Driver Duct Dilation 


\section{SUMMARY}

An analysis was conducted to evaluate the effect of an integrally finned fuel pin spacer design on fuel pin and subassembly irradiation performance. Such a concept with a fin-on-fin design was found to significantly reduce coolant temperature gradients relative to those obtained with the current reference wire wrap design. The temperature redistribution was found to be primarily the result of coolant flow redistribution as affected by subchannel flow areas rather than spacer induced cross-flow mixing. A two fin design with minimum fin width was found to be optimum from the standpoint of coolant pressure drop with potential for a pressure drop less than obtained with a comparative wire wrap design.

The reduced coolant temperature gradients resulted in reduced peak $\mathrm{clad}$ ding temperature and increased subassembly duct wall temperatures. Structural analysis of the integrally finned cladding design showed the reduced temperature effect on the cladding to be offset by strain concentrations associated with the integral fin geometry. Comparison of predicted strains showed local strain to be higher for the integral fin design than for the reference wire wrap design. Furthermore, the increase in subassembly duct wall temperature associated with the integral fin cladding designs was found to significantly reduce the predicted duct design lifetime (from $190 \mathrm{MWd} / \mathrm{kg}$ to $130 \mathrm{MWd} / \mathrm{kg}$ ) for the case evaluated. It is noted that these latter results are dependent upon the materials correlations which were used. Materials with significantly improved irradiation performance properties could alter these results.

It is concluded that an integrally finned cladding design is inferior to the reference cylindrical tube design from the standpoint of fuel pin and subassembly irradiation performance. It is recommended that additional work not be conducted to develop an integrally finned design for utilization with the current reference cladding and duct material (i.e. $20 \%$ CW 316 stainless steel). 


\section{INTRODUCTION}

The current reference fuel pin spacer design for Liquid Metal Fast Breeder Reactors (LMFBRs) consists of a single wire, wrapped around the outside of the fuel pin, with a nominal twelve inch pitch. The principle functions of the spacer are to space the fuel pins within the hexagonal subassembly array to preclude pin-to-pin contact and to promote coolant mixing. Alternate spacer systems which serve the same spacer function but with reduced coolant pressure drops and peak coolant temperatures are desirable provided they do not compromise the overall fuel pin subassembly performance. Alternate spacer systems being considered include improved wire wrap designs, grid spacers and integrally finned cladding. Improved wire wrap designs are currently being evaluated by GE-FBRD $(1)$ while both GE-FBRD $(2,3)$ and Westinghouse Advanced Reactor Division (W-ARD) $(4,5)$ are evaluating grid spacer designs. No known work has previously been conducted in this country on the integrally finned cladding design. The major emphasis on this concept has come from the Federal Republic of Germany. $(6,7,8,9)$

Published results from German work have indicated the integrally finned design to be a promising spacer concept. As a consequence, HEDL conducted an independent analysis to evaluate the potential merits of an integrally finned design with the objective of determining whether or not a testing program should be pursued to develop this concept. The purpose of this report is to summarize the results of that analysis and document the recommendations.

\section{DISCUSSION OF ANALYSIS AND SUMMARY OF RESULTS}

Analysis of the integral fin design consisted of determining the optimum fin configurations by evaluating the effects on:

1. Subassembly thermal/hydraulics,

2. Fuel pin structural performance,

3. Subassembly duct performance. 


\section{A. Thermal/Hydraulic Analysis}

Thermal/hydraulic calculations were performed using the computer program COBRA-IIIC. (10) Calculations were made for 19,61 and 217 pin subassemblies containing fuel pins with 2, 4 and 6 integral fin spacers. Calculations were also made for a comparative wire wrap design for each subassembly size. Standard Experimental Breeder Reactor \#2 (EBR-II) duct, bundle and wire wrap dimensions were used for the 19 and 61 pin subassembly configurations. Fast Flux Test Facility (FFTF) duct, bundle and wire wrap dimensions were used for the 217 pin subassemblies. Pin diameter for all cases considered was 0.230 inches. Integral fin height for each case was sized such that the across-flats bundle dimension matched the design envelope for the comparative wire wrap bundle. Fin width and number of fins per pin were evaluated as design variables. Fin cross-sections were assumed to be rectangular for ease of calculating coolant subchannel flow areas. All integral fin designs evaluated were fin-on-fin. Fin-on-pin designs were considered to have no advantage over a wire wrap design and were not evaluated. Evaluation of each design concept for a given subassembly size was made under the constraints of constant subassembly power, coolant inlet temperature and mixed mean coolant outlet temperature. Thermal/hydraulic performance of the various integral fin desians was based on comparing the pressure drop, peak coolant temperature, and coolant temperature adjacent to the duct wall with that for the comparative wire wrap subassembly. Results of the analyses are summarized in Tables I, II, and III for the 19,61 and 217 pin configurations, respectively.

The 19 pin subassembily configurations were evaluated primarily to expedite and simplify code checkout and to gain initial insight on the effect of integral fin spacers. The 19 pin subassembly was also used to evaluate the effects of fin width, spacer pitch and mixing effects on temperature distribution and coolant pressure drop. Operational experience obtained with COBRA-III C by evaluating the 19 pin subassemblies showed it to be a long running code.

Results of these analyses, however, provided justification for code simplification to expedite evaluation of the 61 and 217 pin subassemblies. 
TABLE I

COMPARISON OF THERMAL/HYDRAULIC PERFORMANCE FOR 19 PIN

SUBASSEMBLIES UTILIZING WIRE WRAP SPACERS AND INTEGRAL FIN SPACERS

\begin{tabular}{|c|c|c|c|c|c|c|c|c|c|}
\hline CASE & $\begin{array}{l}\text { SPACER } \\
\text { TYPE }\end{array}$ & $\begin{array}{l}\text { \# SPACERS } \\
\text { PER PIN } \\
\end{array}$ & $\begin{array}{l}\text { SPACER } \\
\text { PITCH } \\
\text { (inches) }\end{array}$ & $\begin{array}{c}\text { WIRE DIAMETER } \\
\text { OR FIN HEIGHT } \\
\text { (inches) } \\
\end{array}$ & $\begin{array}{l}\text { SPACER } \\
\text { WIDTH } \\
\text { (inches) } \\
\end{array}$ & $\begin{array}{l}\text { MAXIMUM } \\
\text { COOLANT } \\
\text { TEMPERATURE } \\
\begin{array}{l}\left({ }^{\circ} \mathrm{F}\right) \\
\end{array}\end{array}$ & $\begin{array}{l}\text { MID-FLAT } \\
\text { COOLANT } \\
\text { TEMPERATURE } \\
\left({ }^{\circ} \mathrm{F}\right) \\
\end{array}$ & $\begin{array}{l}\text { COOLANT } \\
\text { RADIAL } \triangle T \\
\left(\mathrm{~F}^{\circ}\right)\end{array}$ & $\begin{array}{l}\text { PRESSURE DROP } \\
\text { ACROSS CORE } \\
\text { REGION } \\
\text { (PSI) } \\
\end{array}$ \\
\hline $\begin{array}{l}1 \\
2 \\
3 \\
4 \\
5 \\
6 \\
7 \star \\
8^{\star}\end{array}$ & $\begin{array}{c}\text { Wire Wrap } \\
\text { Wire Wrap } \\
\text { Fin } \\
\text { Fin } \\
\text { Fin } \\
\text { Fin } \\
\text { Wire Wrap } \\
\text { Fin }\end{array}$ & $\begin{array}{l}1 \\
1 \\
2 \\
4 \\
6 \\
6 \\
1 \\
6\end{array}$ & $\begin{array}{r}12 \\
6 \\
12 \\
12 \\
12 \\
24 \\
12 \\
12\end{array}$ & $\begin{array}{l}0.042 \\
0.042 \\
0.0257 \\
0.0257 \\
0.0257 \\
0.0257 \\
0.042 \\
0.0257\end{array}$ & $\begin{array}{c}-- \\
-\overline{0} \\
0.0257 \\
0.0257 \\
0.0257 \\
0.0257 \\
\overline{0.0257}\end{array}$ & $\begin{array}{r}1059 \\
1057 \\
975 \\
980 \\
984 \\
984 \\
1058 \\
978\end{array}$ & $\begin{array}{l}925 \\
919 \\
942 \\
938 \\
936 \\
935 \\
913 \\
939\end{array}$ & $\begin{array}{r}134 \\
138 \\
33 \\
42 \\
48 \\
49 \\
145 \\
39\end{array}$ & $\begin{array}{r}7.1 \\
7.2 \\
6.6 \\
8.9 \\
11.5 \\
11.5 \\
6.2 \\
7.5\end{array}$ \\
\hline
\end{tabular}

$D$

\section{ALL CASES}

$\begin{array}{lll}\text { Subassembly Power } & =342 \mathrm{~kW} \\ \text { Core Height } & =13.5 \text { inches } \\ \text { Coolant Inlet Temperature } & =700^{\circ} \mathrm{F} \\ \text { Mixed Mean Coolant Outlet Temperature } & =957^{\circ} \mathrm{F} \\ \text { Coolant Average Axial } \Delta \mathrm{T} & =275 \mathrm{~F}^{\circ} \\ \text { Pin Diameter } & =0.230 \text { inches }\end{array}$

*Pressure drop values are low as a consequence of no spacer induced flow mixing. 
TABLE II

COMPARISON OF THERMAL/HYDRAULIC PERFORMANCE FOR 61 PIN

SUBASSEMBLIES UTILIZING WIRE WRAP SPACERS AND INTEGRAL FIN SPACERS

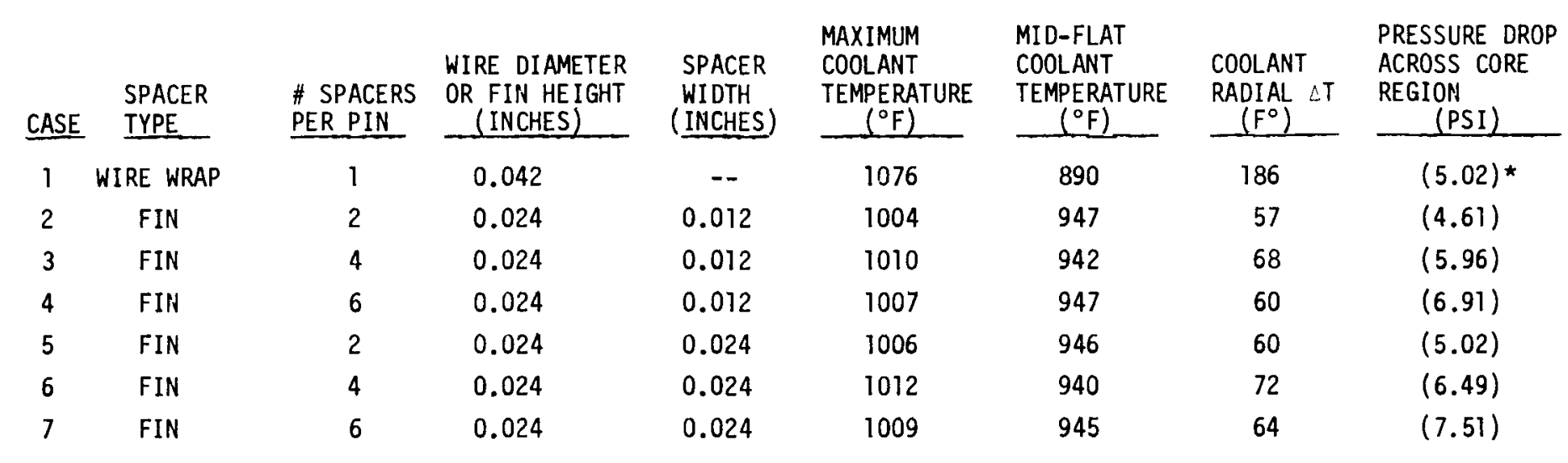

ALL CASES

$\begin{array}{lll}\text { Spacer Pitch } & =12 \text { inches } \\ \text { Subassembly Power } & =841 \mathrm{~kW} \\ \text { Core Height } & =13.5 \text { inches } \\ \text { Coolant Inlet Temperature } & =700^{\circ} \mathrm{F} \\ \text { Mixed Mean Coolant Outlet Temperature } & =975^{\circ} \mathrm{F} \\ \text { Coolant Average Axial } \Delta \mathrm{T} & =275 \mathrm{~F}^{\circ} \\ \text { Pin Diameter } & =0.230 \text { inches } \\ \text { No Flow Mixing } & \end{array}$

*Pressure drop values are low as a consequence of no spacer induced flow mixing. 
TABLE II I

COMPARISON OF THERMAL/HYDRAULIC PERFORMANCE FOR 217 PIN

SUBASSEMBLIES UTILIZING WIRE WRAP SPACERS AND INTEGRAL FIN SPACERS

\begin{tabular}{|c|c|c|c|c|c|c|c|c|}
\hline CASE & $\begin{array}{l}\text { SPACER } \\
\text { TYPE } \\
\end{array}$ & $\begin{array}{l}\text { \# SPACERS } \\
\text { PER PIN } \\
\end{array}$ & $\begin{array}{l}\text { WIRE DIAMETER } \\
\text { OR FIN HEIGHT } \\
\text { (INCHES) } \\
\end{array}$ & $\begin{array}{l}\text { SPACER } \\
\text { WIDTH } \\
\text { (INCHES) }\end{array}$ & $\begin{array}{l}\text { MAXIMUM } \\
\text { COOL ANT } \\
\text { TEMPERATURE } \\
\left({ }^{\circ} \mathrm{F}\right) \\
\end{array}$ & $\begin{array}{l}\text { MID-FLAT } \\
\text { COOLANT } \\
\text { TEMPERATURE } \\
\left({ }^{\circ} \mathrm{F}\right) \\
\end{array}$ & $\begin{array}{l}\text { COOLANT } \\
\text { RADIAL } \triangle T \\
\left(F^{\circ}\right) \\
\end{array}$ & $\begin{array}{l}\text { PRESSURE DROP } \\
\text { ACROSS CORE } \\
\text { REGION } \\
(\text { PSI) } \\
\end{array}$ \\
\hline 2 & Fin & 2 & 0.030 & 0.012 & 1022 & 960 & 62 & $(16.58)$ \\
\hline 3 & Fin & 4 & 0.030 & 0.012 & 1022 & 955 & 67 & $(21.00)$ \\
\hline
\end{tabular}

\section{ALL CASES}

$\begin{array}{ll}\text { Spacer Pitch } & =12 \text { inches } \\ \text { Subassembly Power } & =6722 \mathrm{~kW} \\ \text { Core Height } & =36 \text { inches } \\ \text { Coolant Inlet Temperature } & =600^{\circ} \mathrm{F} \\ \text { Mixed lean Coolant Outlet Temperature } & =986^{\circ} \mathrm{F} \\ \text { Cool ant Average Axial } \Delta \mathrm{T} & =386 \mathrm{~F}^{\circ} \\ \text { Pin Diameter } & =0.230 \text { inches } \\ \text { No Flow Mixing } & \end{array}$

*Pressure drop values are low as a consequence of no spacer induced flow mixing. 
Specifically, the results (Table I) show that the coolant temperature distribution is primarily affected by flow distribution as determined by the flow channel areas rather than due to flow mixing induced by the spacer system. This can be seen by comparing the results for cases 7 and 8 with those for cases 1 and 5 in Table 1 . As a consequence, spacer induced flow mixing was eliminated in the COBRA-IIIC model to reduce code running time and expedite analyses of the 61 and 217 pin subassemblies. In addition, symmetry was utilized to model only one sixth of the crossusection (i.e. a triangular segment) for the larger subassemblies and further expedite the analyses. It is noted that the elimination of spacer induced mixing does significantly affect the pressure drop results. As such, the pressure drop values shown in Tables II and III should be viewed with caution and only those values shown in Table I for the 19 pin subassemblies should be used for evaluating the absolute effects of integral fins on pressure drop.

Results of the analyses show that an integral fin design reduces the peak coolant temperature while increasing the minimum coolant temperature. Varying the number of fins and/or fin width has little effect except on pressure drop. Varying the spacer pitch between 6 and 24 inches, was found to have an insignificant effect on both temperature distribution and pressure drop.

The extent of temperature redistribution as affected by the integral fins is a function of subassembly size (i.e. number of pins). The drop in peak c001ant temperature associated with going from a wire wrap to an integral fin design decreases with increasing subassembly size. The increase in temperature of the coolant adjacent to the duct walls increases with increasing subassembly size. This result is a consequence of the relative flow split between exterior (i.e. edge and corner) and interior flow channels as affected by subassembly size and the introduction of integral fins. To illustrate this point consider the flow split for the 61 and 217 pin subassemblies analyzed. For the wire wrapped 61 and 217 pin subassemblies evaluated (case 1 in Tables II and III) the relative total flow in the exterior channels is $41 \%$ and $25 \%$ respective7y. For the comparative 2-fin designs (case 2 in Tables II and III) the relative total flow in the exterior channels is $28 \%$ and $15 \%$ respectively. The relative total flow diverted by the fins is $13 \%$ for the 61 pin subassembly 
and $10 \%$ for the 217 pin subassembly. These correspond to relative reductions in exterior flow of $32 \%$ and $39 \%$ compared to increases of $22 \%$ and $13 \%$ in interior flow for the 61 and 217 pin subassemblies, respectively. The corresponding increases in exterior coolant temperatures due to the fins are $57^{\circ} \mathrm{F}$ and $75^{\circ} \mathrm{F}$. The decreases in maximum coolant temperatures are $72^{\circ} \mathrm{F}$ and $31^{\circ} \mathrm{F}$ for the 61 and 217 pin subassemblies, respectively.

In summary, an integral fin spacer concept can be expected to effectively reduce the radial temperature gradients within an LMFBR subassembly. From the standpoint of thermal hydraulics, the optimum fin design would incorporate two fins with the minimum practical fin width. Such a design would allow the maximum mixed mean coolant outlet temperature with the minimum peak coolant temperature and pressure drop.

\section{B. Fuel Pin Structural Analysis}

Fuel pin structural analys is was performed under the direction of HEDL by the Control Data Corporation using the MARC finite element computer code. The objectives of the analysis were to identify the optimum fin geometry and to evaluate the potentially improved fuel pin performance consistent with the reduced peak cladding temperature indicated by the thermal/hydraulic results. To achieve these objectives, the following sequence of steps was followed:

1. Perform heat transfer and elastic analyses on five geometrical configurations to establish the optimum integrally finned cladding design from the standpoint of mechanical and thermal loads.

2. Perform inelastic analysis on the selected optimum design (including thermal creep, irradiation creep, and irradiation induced swelling).

3. Perform comparative analysis for a cylindrical tube geometry to allow evaluation of the integral fin geometry.

4. Repeat the step 2 analysis with all parameters held fixed and temperature reduced consistent with the thermal hydraulic analys is. 
The integral fin cladding model selected for analysis consisted of a cylindrical tube of constant wall thickness with six helical integral fins equally spaced in the circumferential direction as shown in Figure 1 . Because of the symmetry of the geometry and loading conditions, only one twelfth of the cross-section (shaded region, Figure 1) was modeled. Figure 2 summarizes the boundary conditions associated with the heat transfer and stress analyses.

For the heat transfer analysis, a constant heat flux was assumed along the inner boundary. Along the outer boundary a convective heat transfer surface characterized by a constant film drop and bulk coolant temperature was assumed. Insulated thermal boundaries were assumed to exist along geometrical lines of symmetry.

Roller supports were assumed along the two geometrical lines of symmetry for the stress analysis. The mechanical (pressure) loading was assumed to increase linearly with time based on the predicted buildup of fission gas pressure.

The five integrally finned cladding geometries analyzed are summarized in Table IV. The main parameters which were varied are fillet radius, fin width and wall thickness. Figure 3 schematically summarizes the five geometries plus the reference case cylindrical tube. Table $V$ lists the environmental conditions used for the thermal and elastic stress analysis to select the optimum fin design. It is noted that these conditions correspond to a fuel pin operating in EBR-II at a peak linear power of $16 \mathrm{~kW} / \mathrm{ft}$ with a gas pressure corresponding to a burnup of $200 \mathrm{MWd} / \mathrm{kg}$. There is no significance attached to this set of conditions other than it does provide a design envelope for optimizing fin geometry.

Table VI summarizes the environmental conditions used in the inelastic analyses. These conditions correspond to a fuel pin operating in EBR-II at a peak linear power of $13.6 \mathrm{~kW} / \mathrm{ft}$ with a creep time of 14,000 hours corresponding to a burnup of approximately $150 \mathrm{MWd} / \mathrm{kg}$. These conditions were selected as representative of those which might be utilized in an irradiation 


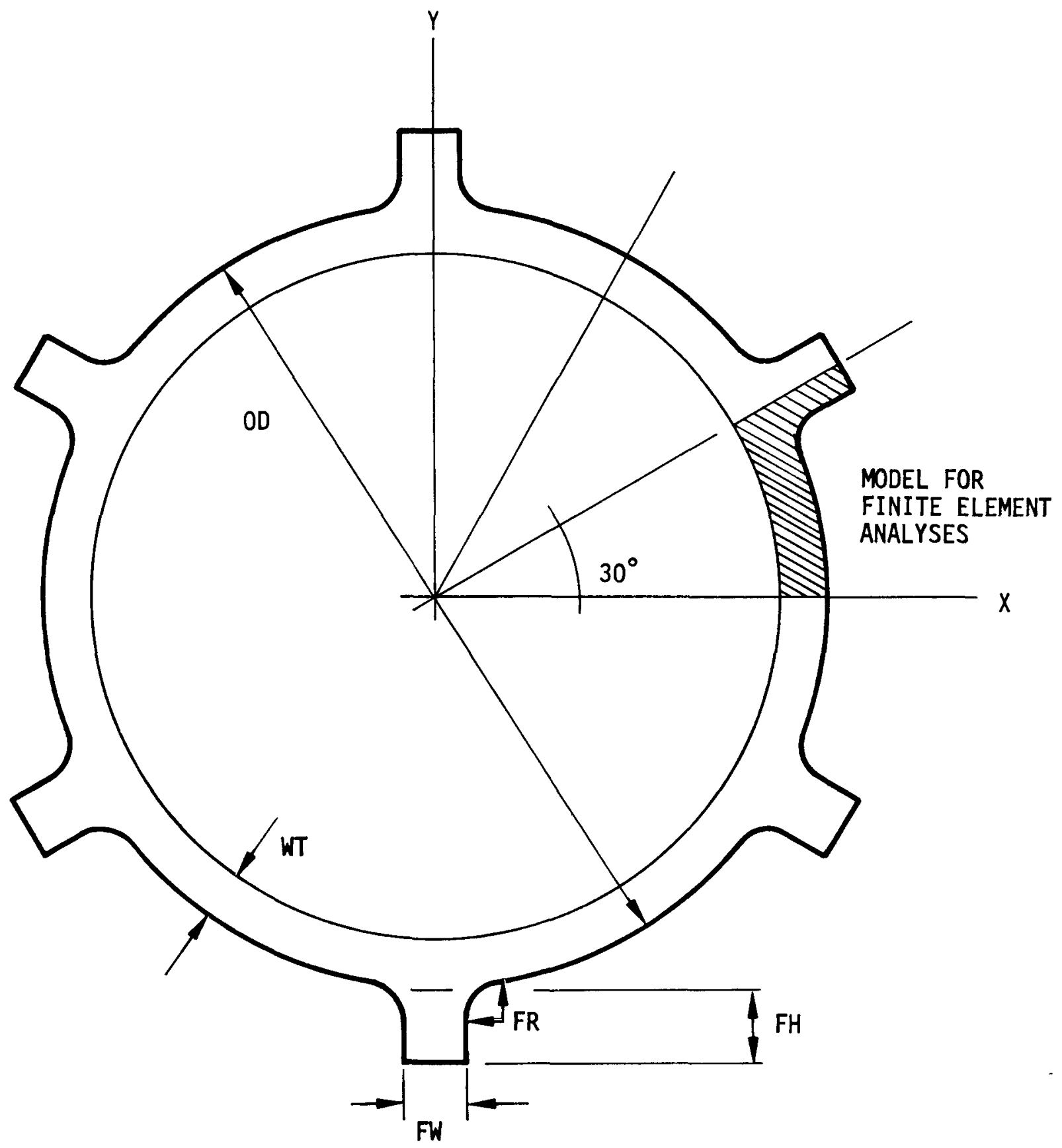

OD: OUTER DIAMETER

WT: WALL THICKNESS

FH: FIN HEIGHT

FW: FIN WIDTH

FR: FILLET RADIUS

FIGURE 1. Axially Finned Fuel Cladding Cross-Section. 

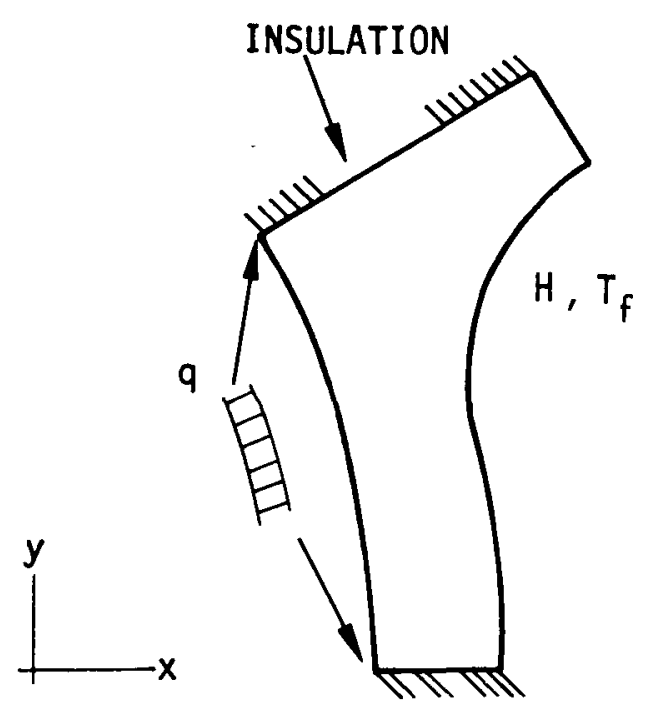

THERMAL ANALYSIS

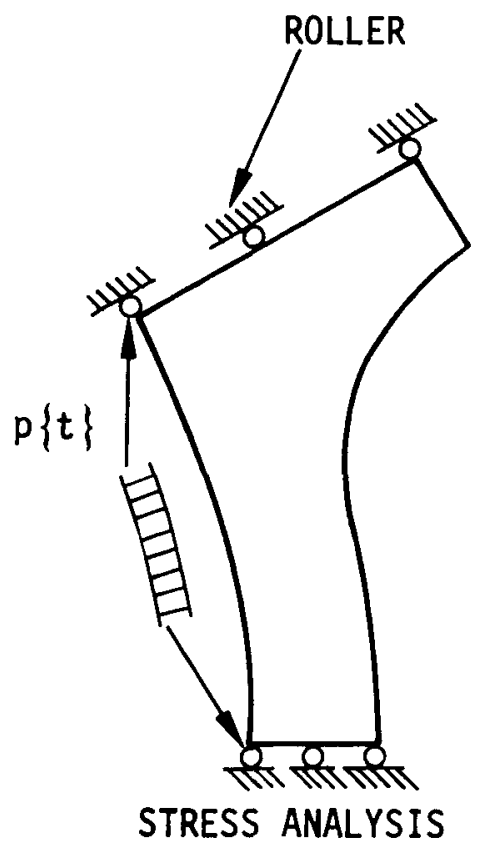

(a) AXIALLY FINNED CLAD

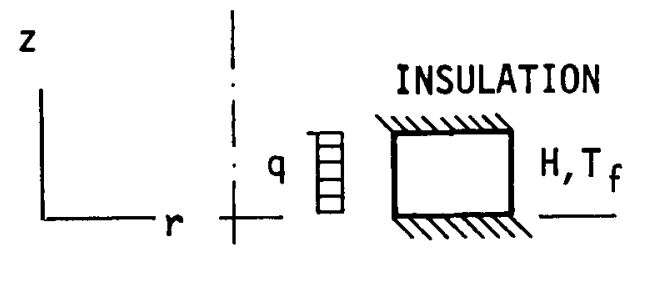

THERMAL ANALYSIS

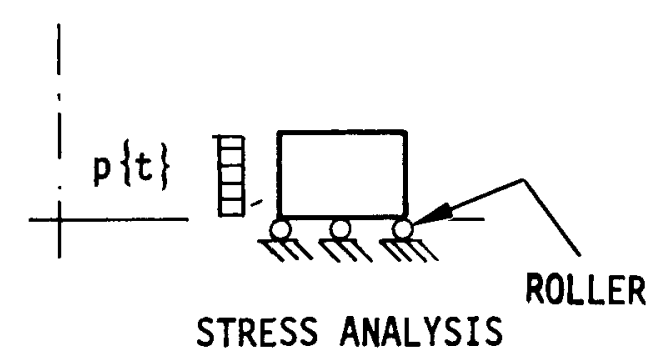

(a) CYLINDRICAL TUBE

FIGURE 2. Boundary Conditions of Axially Finned Cladding Models and the Cylindrical Tube. 

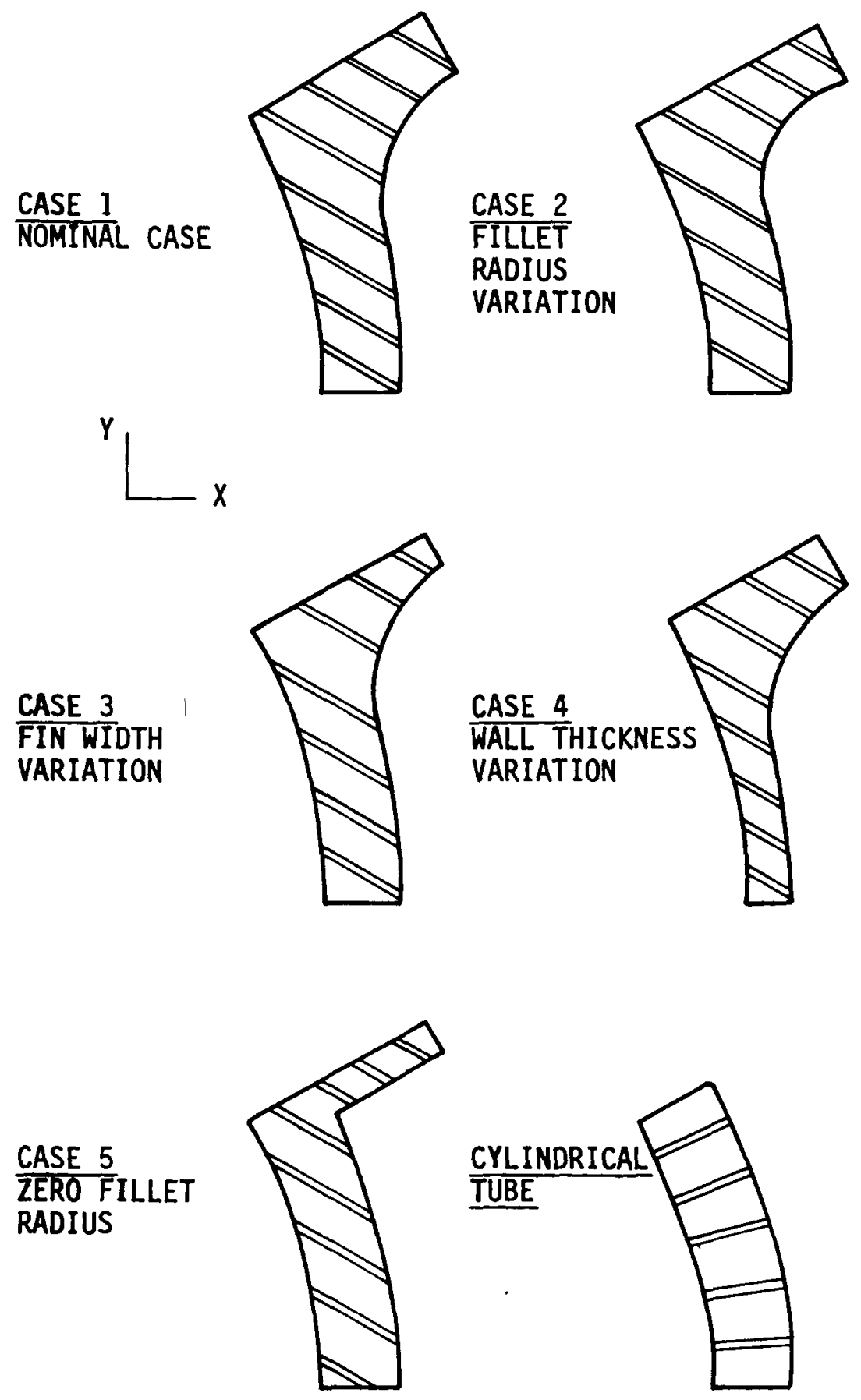

FIGURE 3. Geometric Configurations of Axially Finned Cladding Models and the Cylindrical Tube. 
TABLE IV

FUEL CLADDING GEOMETRIC CONFIGURATIONS

\begin{tabular}{|c|c|c|c|c|c|}
\hline \multirow{2}{*}{ GEOMETRIC CONFIGURATIONS } & \multicolumn{4}{|c|}{ DIMENSIONS } & \\
\hline & $\begin{array}{l}\text { OUTER } \\
\text { DIAMETER } \\
{[\text { IN }]} \\
\end{array}$ & $\begin{array}{l}\text { WALL } \\
\text { THICKNESS } \\
\text { \{IN\} }\end{array}$ & $\begin{array}{l}\text { FIN } \\
\text { HEIGHT } \\
\text { \{IN\} }\end{array}$ & $\begin{array}{l}\text { FIN } \\
\text { WIDTH } \\
\{\text { IN }\} \\
\end{array}$ & $\begin{array}{l}\text { FILLET } \\
\text { RADIUS } \\
\{\text { IN }\}\end{array}$ \\
\hline CASE $1-\operatorname{NAMINAL~}_{\text {CASE }}^{\text {NOM }}$ & 0.2300 & 0.0150 & 0.0235 & 0.0235 & 0.0310 \\
\hline $\begin{array}{c}\text { CASE } 2 \text { - FILLET RADIUS } \\
\text { VARIATION }\end{array}$ & 0.2300 & 0.0150 & 0.0235 & 0.0235 & 0.0200 \\
\hline $\begin{array}{r}\text { CASE } 3 \text { - FIN WIDTH } \\
\text { VARIATION }\end{array}$ & 0.2300 & 0.0150 & 0.0235 & 0.01175 & 0.0310 \\
\hline $\begin{array}{c}\text { CASE } 4 \text { - WALL THICKNESS } \\
\text { VARIATION }\end{array}$ & 0.2300 & 0.0100 & 0.0235 & 0.0235 & 0.0310 \\
\hline CASE 5 - ZERO FILLET & 0.2300 & 0.0150 & 0.0235 & 0.01175 & 0.0000 \\
\hline CYLINDRICAL TUBE & 0.2300 & 0.0150 & 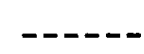 & --.---- & $-\cdots-$ \\
\hline
\end{tabular}




\section{TABLE V}

ENVIRONMENTAL CONDITIONS FOR STEADY STATE THERMAL AND ELASTIC STRESS ANALYSES

\begin{tabular}{|c|c|c|c|c|c|c|c|}
\hline \multirow{2}{*}{$\begin{array}{l}\text { ENVIRONMENTAL } \\
\text { CONDITIONS }\end{array}$} & \multirow{2}{*}{$\begin{array}{l}\text { CASE } 1 \\
\text { \{NOMINAL } \\
\text { CASE }\end{array}$} & \multirow{2}{*}{$\begin{array}{l}\text { CASE } 2 \\
\text { \{FILLET } \\
\text { RADIUS } \\
\text { VARIA- } \\
\text { TION\} } \\
\end{array}$} & \multirow{2}{*}{$\begin{array}{l}\text { CASE } 3 \\
\text { \{FIN } \\
\text { WIDTH } \\
\text { VARIA- } \\
\text { TION\} } \\
\end{array}$} & \multirow{2}{*}{$\begin{array}{l}\text { CASE } 4 \\
\text { \{WALL } \\
\text { THICKNESS } \\
\text { VARIA- } \\
\text { TION\} } \\
\end{array}$} & \multirow{2}{*}{$\begin{array}{l}\text { CASE } 5 \\
\text { \{LIMIT- } \\
\text { ING } \\
\text { CASE }\}\end{array}$} & \multicolumn{2}{|c|}{ CYLINDRICAL TUBE } \\
\hline & & & & & & TUBE 1 & TUBE 2 \\
\hline $\begin{array}{l}\text { FILM COEFFICIENT H } \\
\left\{\text { BTU/IN }{ }^{2}{ }^{\circ} \mathrm{F}-\mathrm{HR}\right\}\end{array}$ & 243.0 & 243.0 & 243.0 & 243.0 & 243.0 & 243.0 & 243.0 \\
\hline $\begin{array}{l}\text { BULK COOLANT TEM- } \\
\text { PERATURE }\left\{^{\circ} \mathrm{F}\right\}\end{array}$ & 983.42 & 983.42 & 983.42 & 983.42 & 983.42 & 1044.2 & 873.1 \\
\hline $\begin{array}{l}\text { SEGMENT POWER } \\
\{\text { BTU/IN-HR\} }\end{array}$ & $\begin{array}{l}0.4478 \\
\times 10^{4}\end{array}$ & $\begin{array}{l}0.4478 \\
\times 10^{4}\end{array}$ & $\begin{array}{l}0.4478 \\
\times 10^{4}\end{array}$ & $\begin{array}{l}0.4478 \\
\times 10^{4}\end{array}$ & $\begin{array}{l}0.4478 \\
\times 10^{4}\end{array}$ & $\begin{array}{l}0.3245 \\
\times 10^{4}\end{array}$ & $\begin{array}{l}0.3860 \\
\times 10^{4}\end{array}$ \\
\hline $\begin{array}{l}\text { HEAT FLUX } q \\
\left\{B T U / I^{2}-H R\right\}\end{array}$ & $\begin{array}{l}0.713 \\
\times 10^{4}\end{array}$ & $\begin{array}{l}0.713 \\
\times 10^{4}\end{array}$ & $\begin{array}{l}0.713 \\
\times 10^{4}\end{array}$ & $\begin{array}{l}0.679 \\
\times 10^{4}\end{array}$ & $\begin{array}{l}0.713 \\
\times 10^{4}\end{array}$ & $\begin{array}{l}0.516 \\
\times 10^{4}\end{array}$ & $\begin{array}{l}0.615 \\
\times 10^{4}\end{array}$ \\
\hline $\begin{array}{l}\text { INTERNAL PRESSURE } \\
\{\text { PSI }\}\end{array}$ & 1930.0 & 1930.0 & 1930.0 & 1930.0 & 1930.0 & 1930.0 & 1930.0 \\
\hline $\begin{array}{l}\text { AXIAL LOCATION \{IN\} } \\
\text { - FROM THE BOTTOM } \\
\text { OF THE FUEL }\end{array}$ & 8.25 & 8.25 & 8.25 & 8.25 & 8.25 & 13.50 & 6.75 \\
\hline
\end{tabular}


TABLE VI

ENVIRONMENTAL CONDITIONS FOR CREEP ANALYSES

\begin{tabular}{|c|c|c|c|c|c|c|c|}
\hline \multirow{2}{*}{$\begin{array}{l}\text { ENVIRONMENTAL } \\
\text { CONDITIONS }\end{array}$} & \multicolumn{4}{|c|}{ CASE 2} & \multicolumn{2}{|c|}{ CYLINDRICAL TUBE } & \multirow[t]{2}{*}{ CASE 1} \\
\hline & $2 \mathrm{~A}$ & $2 \mathrm{~B}$ & $2 \mathrm{C}$ & 20 & TUBE 1 & TUBE 2 & \\
\hline $\begin{array}{l}\text { Film Coefficient } H \\
\text { (Btu/In }{ }^{2}-{ }^{\circ} \text { F-hr) }\end{array}$ & 243.0 & 243.0 & 243.0 & 243.0 & 243.0 & 243.0 & 243.0 \\
\hline $\begin{array}{l}\text { Bulk Coolant Temperature } \\
(\mathrm{OF})\end{array}$ & 984.0 & 1044.2 & 842.0 & 873.1 & 1044.2 & 873.1 & 984.0 \\
\hline $\begin{array}{l}\text { Segment Power } \\
\text { (Btu/In-hr) }\end{array}$ & $\begin{array}{l}0.3245 \\
\times 10^{4} \\
\end{array}$ & $\begin{array}{l}0.3245 \\
\times 10^{4} \\
\end{array}$ & $\begin{array}{l}0.3860 \\
\times 10^{4} \\
\end{array}$ & $\begin{array}{l}0.3860 \\
\times 10^{4} \\
\end{array}$ & $\begin{array}{l} \\
\times 10^{4.3245} \\
\end{array}$ & $\begin{array}{l}0.3860 \\
\times 10^{4} \\
\end{array}$ & $\begin{array}{r}0.3245 \\
\times 10^{4} \\
\end{array}$ \\
\hline $\begin{array}{l}\text { Heat Flux } q \\
\left.\text { (Btu/In }{ }^{2}-h r\right)\end{array}$ & $\begin{array}{l}0.516 \\
\times 10^{4} \\
\end{array}$ & $\begin{array}{l}0.516 \\
\times 10^{4} \\
\end{array}$ & $\begin{array}{l}0.615 \\
\times 10^{4} \\
\end{array}$ & $\begin{array}{l}0.615 \\
\times 10^{4} \\
\end{array}$ & $\begin{array}{r}{ }^{0.516} \\
\times 10^{4} \\
\end{array}$ & $\begin{array}{l}0.615 \\
\times 10^{4} \\
\end{array}$ & $\begin{array}{l}0.516 \\
\times 10^{4} \\
\end{array}$ \\
\hline $\begin{array}{l}\text { Total Flux } \\
\text { (Neutrons } / \mathrm{Cm}^{2}-\mathrm{sec} \text { ) }\end{array}$ & $\begin{array}{l}1.58 \\
\times 10^{15} \\
\end{array}$ & $\begin{array}{l}1.58 \\
\times 10^{15} \\
\end{array}$ & $\begin{array}{l}2.26 \\
\times 10^{15} \\
\end{array}$ & $\begin{array}{l}2.26 \\
\times 10^{15} \\
\end{array}$ & $\times 10^{1.58}$ & $\begin{array}{r}2.26 \\
\times 10^{15} \\
\end{array}$ & $\begin{array}{r}1.58 \\
\times 10^{15} \\
\end{array}$ \\
\hline $\begin{array}{l}\text { Fast Flux } \\
\left(\text { Neut } / \mathrm{Cm}^{2}-\mathrm{sec}\right)\end{array}$ & $\begin{array}{l}1.32 \\
\times 10^{15} \\
\end{array}$ & $\begin{array}{l}1.32 \\
\times 10^{15} \\
\end{array}$ & $\begin{array}{l}2.13 \\
\times 10^{15} \\
\end{array}$ & $\begin{array}{l}2.13 \\
\times 10^{15} \\
\end{array}$ & $\begin{array}{r}1.32 \\
\times 10^{15} \\
\end{array}$ & $\begin{array}{r}2.13 \\
\times 10^{15} \\
\end{array}$ & $\begin{array}{r}1.32 \\
\times 10^{15} \\
\end{array}$ \\
\hline Average Neutron Energy & 0.757 & 0.757 & 0.910 & 0.910 & 0.757 & 0.910 & 0.757 \\
\hline $\begin{array}{l}\text { Internal Pressure } \\
(\mathrm{psi} / \mathrm{hr})_{\star \star \star}\end{array}$ & 0.0994 & 0.0994 & 0.0994 & 0.0994 & 0.0994 & 0.0994 & $\begin{array}{l}1930.0 \\
\text { psi * }\end{array}$ \\
\hline Total Creep Time (hr) & 14,000 & 14,000 & 14,000 & 14,000 & 14,000 & 14,000 & 5,000 \\
\hline $\begin{array}{l}\text { Axial Location (In) - } \\
\text { From the Bottom of the } \\
\text { Fuel }\end{array}$ & 13.50 & 13.50 & 6.75 & 6.75 & 13.50 & 6.75 & 13.50 \\
\hline
\end{tabular}

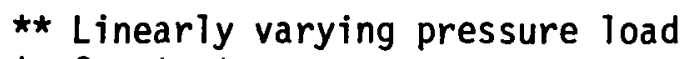

* Constant pressure 
test if the analyses were favorable.

The properties utilized for the analyses are those for $20 \%$ coldworked 316 stainless steel. For completeness these values are summarized in Table VII.

Results of the elastic and thermal stress analyses conducted on the five geometries to select the optimum fin design are summarized in Table VIII. The effective stress is defined by:

$$
\sigma_{\text {eff }}=\frac{1}{\sqrt{2}}\left[\left(\sigma_{x}-\sigma_{y}\right)^{2}+\left(\sigma_{y}-\sigma_{z}\right)^{2}+\left(\sigma_{z}-\sigma_{x}\right) 2+\sigma\left(\tau_{x y}^{2}+\tau_{x z}^{2}+\tau_{y z}^{2}\right)\right]^{\frac{1}{2}}
$$

where $\sigma_{x}, \sigma_{y}, \sigma_{z}=$ normal components of stress

$$
{ }^{\tau} x y,{ }^{\tau} x z, \tau_{y z}=\text { shear components of stress }
$$

Figure 4 shows a temperature contour plot for case 1 typical of those obtained for all five cases. Evaluation of these plots shows the maximum inside diameter temperature occurring under the fin. Increasing either the fillet radius or the width of the fin increases the amount of peaking which occurs. For the cases evaluated, the maximum temperature rise under the fin was $44 \mathrm{~F}^{\circ}$.

Figures 5 and 6 show the effective thermal and pressure stresses, respectively, for case 1 typical of those obtained for all five cases. For the case of thermal stresses, maximum stresses were found to occur in the fillet region along the outer boundary. Pressure stresses, however, were found to concentrate on the inner boundary under the fin.

Reducing the cladding wall thickness (case 4, Table VIII) was found to produce the maximum temperature rise under the fin and an increased effective stress due to pressure loading approximately proportional to the increased mean radius of the fuel pin. However, reducing the wall thickness was found to reduce the thermal stresses due to increased flexibility of the thinner walled cylinder. 
CW 316 STAINLESS STEEL PROPERTIES USED IN ANALYSES

Thermal/Mechanical Properties

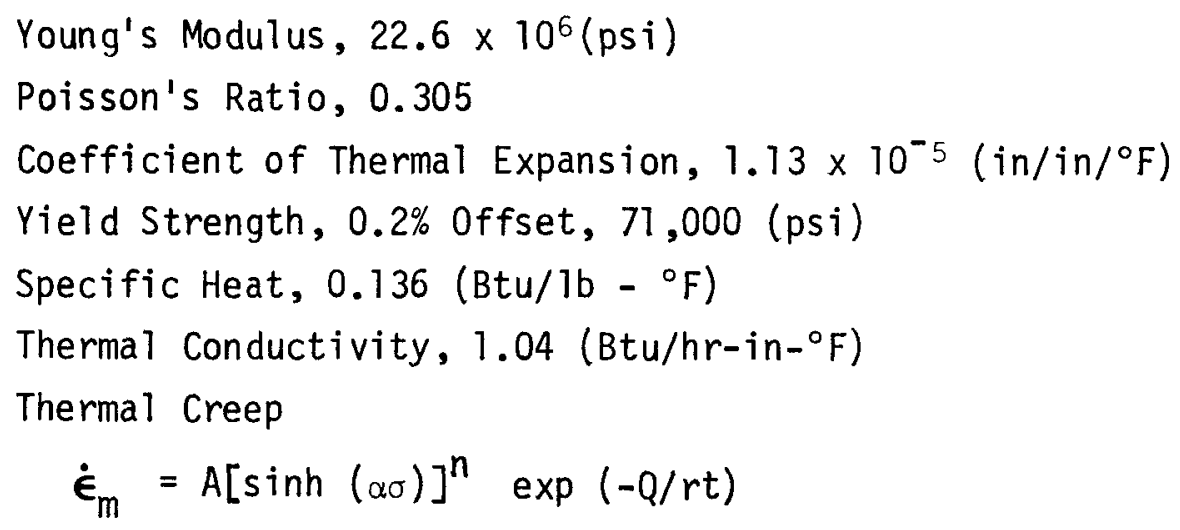

$$
\begin{aligned}
& \dot{\epsilon}_{m}=\text { creep rate (\% per hour) } \\
& A=1.609 \times 10^{5} \exp (14633 / \mathrm{T}) \\
& \alpha=\frac{-5.225 \times 10^{-4}+8.716 \times 10^{-7} \mathrm{~T}}{23.55-0.01796 \mathrm{~T}} \\
& n=24.608-0.01923 \mathrm{~T} \\
& Q=64,000(\mathrm{cal} / \mathrm{mol}) \\
& R=1.987\left(\mathrm{cal} / \mathrm{mol} /{ }^{\circ} \mathrm{k}\right) \\
& T=\text { temperature }\left({ }^{\circ} \mathrm{k}\right) \\
& \sigma=\text { stress }(\mathrm{psi})
\end{aligned}
$$

Irradiation Induced Properties

Irradiation Creep Equation,

$$
\begin{gathered}
\epsilon=1.7 \times 10^{-23} \bar{E}_{\phi \sigma}\left[1-\exp \left(-\bar{E}_{\phi \tau} / 5.5 \times 10^{16}\right)\right] \\
+2.7 \times 10^{-26} \bar{E}_{\phi \sigma \tau}
\end{gathered}
$$

where,

$$
\begin{aligned}
& E \quad=\text { uniaxial strain (in/in) } \\
& \sigma \quad=\text { uniaxial stress (psi) } \\
& \tau \quad=\text { time (hours) } \\
& \phi \quad=\text { flux (neutrons } / \mathrm{cm}^{2}-\mathrm{sec} \text { ) } \\
& \bar{E} \quad=\text { average neutron energy (MeV) }
\end{aligned}
$$


Irradiation Swelling Equation,

$$
\frac{\Delta V}{V_{0}}=R\left[\phi+\frac{1}{\alpha} \ln \quad\left(\frac{1+\exp [\alpha(\tau-\phi)]}{1+\exp (\alpha \tau)}\right)\right]
$$

where,

$$
\begin{aligned}
\frac{\Delta V}{V_{0}}= & \text { swelling }(\%) \\
\phi= & \text { neutron fluence } / 10^{22} \text { (neutrons } / \mathrm{cm}^{2}, \overline{\mathrm{E}}>0.1 \mathrm{MeV} \text { ) } \\
T= & \text { irradiation temperature }\left({ }^{\circ} \mathrm{C}\right) \\
R= & \exp (\mathrm{B}) \\
B= & -88.5499+0.531072 \mathrm{~T}-1.24156 \times 10^{-3} \mathrm{~T}^{2} \\
& +1.37215 \times 10^{-6} \mathrm{~T}^{3}-6.14 \times 10^{-10} \mathrm{~T}^{4} \\
\tau= & \exp \left[-16.7382+0.130532 \mathrm{~T}-3.81081 \times 10^{-4} \mathrm{~T}^{2}\right. \\
& \left.+5.51979 \times 10^{-7} \mathrm{~T}^{3}-3.26491 \times 10^{-10} \mathrm{~T}^{4}\right] \\
\alpha= & -1.11667+6.88889 \times 10^{-3} \mathrm{~T}
\end{aligned}
$$


TABLE VIII

MAXIMUM TEMPERATURES AND EFFECTIVE STRESSES OF AXIALLY FINNED MODELS

(CASE 1 THROUGH CASE 5)

\begin{tabular}{|c|c|c|c|c|c|}
\hline & Case 1 & Case 2 & Case 3 & Case 4 & Case 5 \\
\hline & $\begin{array}{l}\text { Nominal } \\
\text { Case }\end{array}$ & $\begin{array}{l}\text { Fillet Radius } \\
\text { Variation }\end{array}$ & $\begin{array}{l}\text { Fin Width } \\
\text { Variation }\end{array}$ & $\begin{array}{l}\text { Wall Thick- } \\
\text { ness } \\
\text { Variation }\end{array}$ & $\begin{array}{l}\text { Zero Fillet } \\
\text { Radius }\end{array}$ \\
\hline (1) Max. Surface Nodal Temperature $\left({ }^{\circ} \mathrm{F}\right)$ & 1141 & 1129 & 1130 & 1116 & 1106 \\
\hline $\begin{array}{l}\text { (2) Max. Temperature }\left({ }^{\circ} \mathrm{F}\right) \\
\text { Gradient Between Inner and Outer } \\
\text { Surface of the Clad } \\
\end{array}$ & 136 & 128 & 127 & 110 & 96 \\
\hline $\begin{array}{l}\text { (3) Max. Temperature }\left({ }^{\circ} \mathrm{F}\right) \\
\text { Gradient Along Inner } \\
\text { Surface of the Clad } \\
\end{array}$ & 33 & 23 & 24 & 44 & 0 \\
\hline (4) Max. Effective Stress (Therma 1) - ksi & 15.4 & 14.1 & 14.1 & 10.5 & 12.8 \\
\hline $\begin{array}{l}\text { (5) Max. Effective Stress } \\
\text { (Pressure) - ksi }\end{array}$ & 15.8 & 15.9 & 16.0 & 23.9 & 15.5 \\
\hline
\end{tabular}




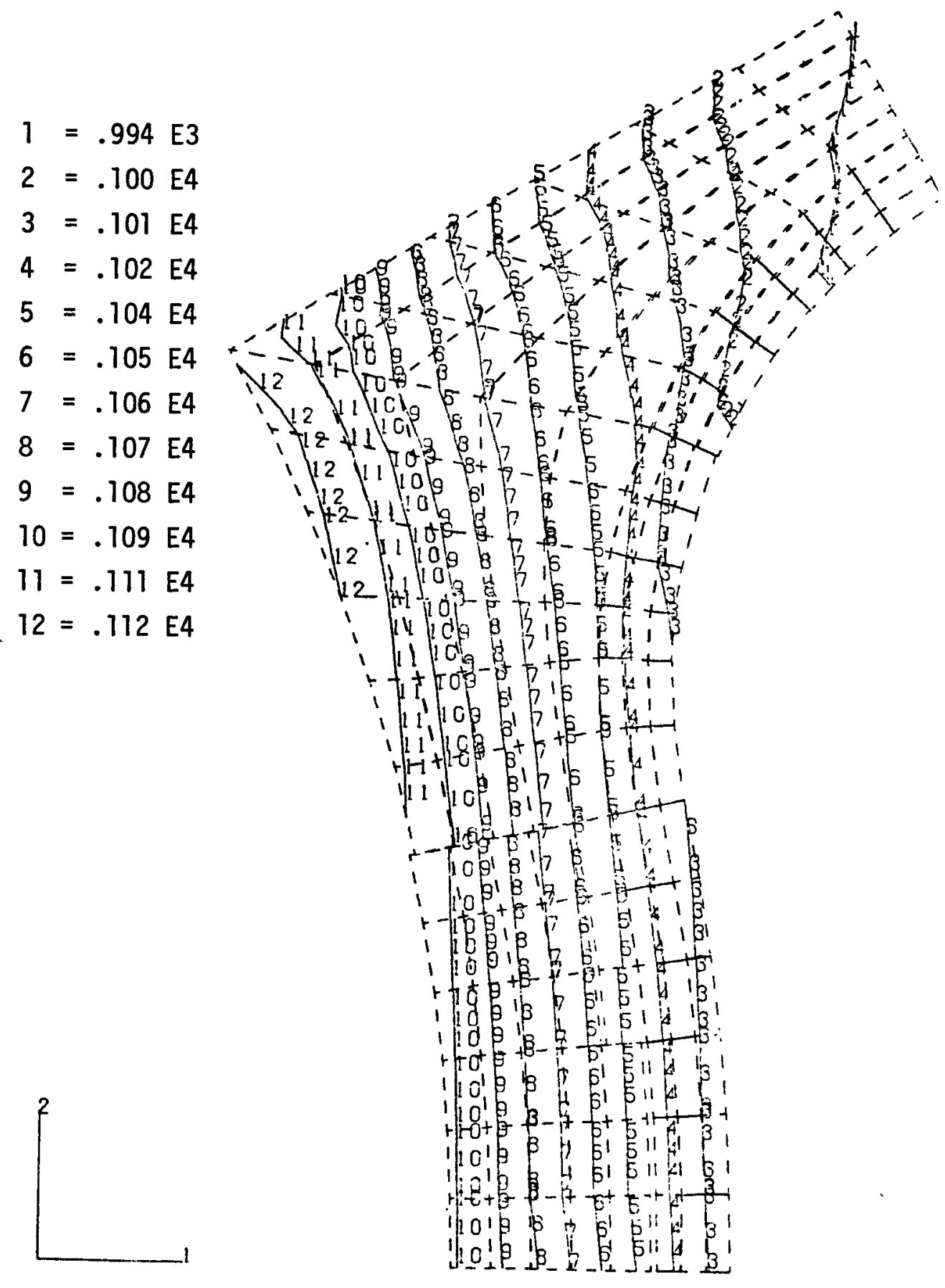

FIGURE 4. Steady State Temperature Distribution (Case 1: Axial Location = 8.25 in.) 


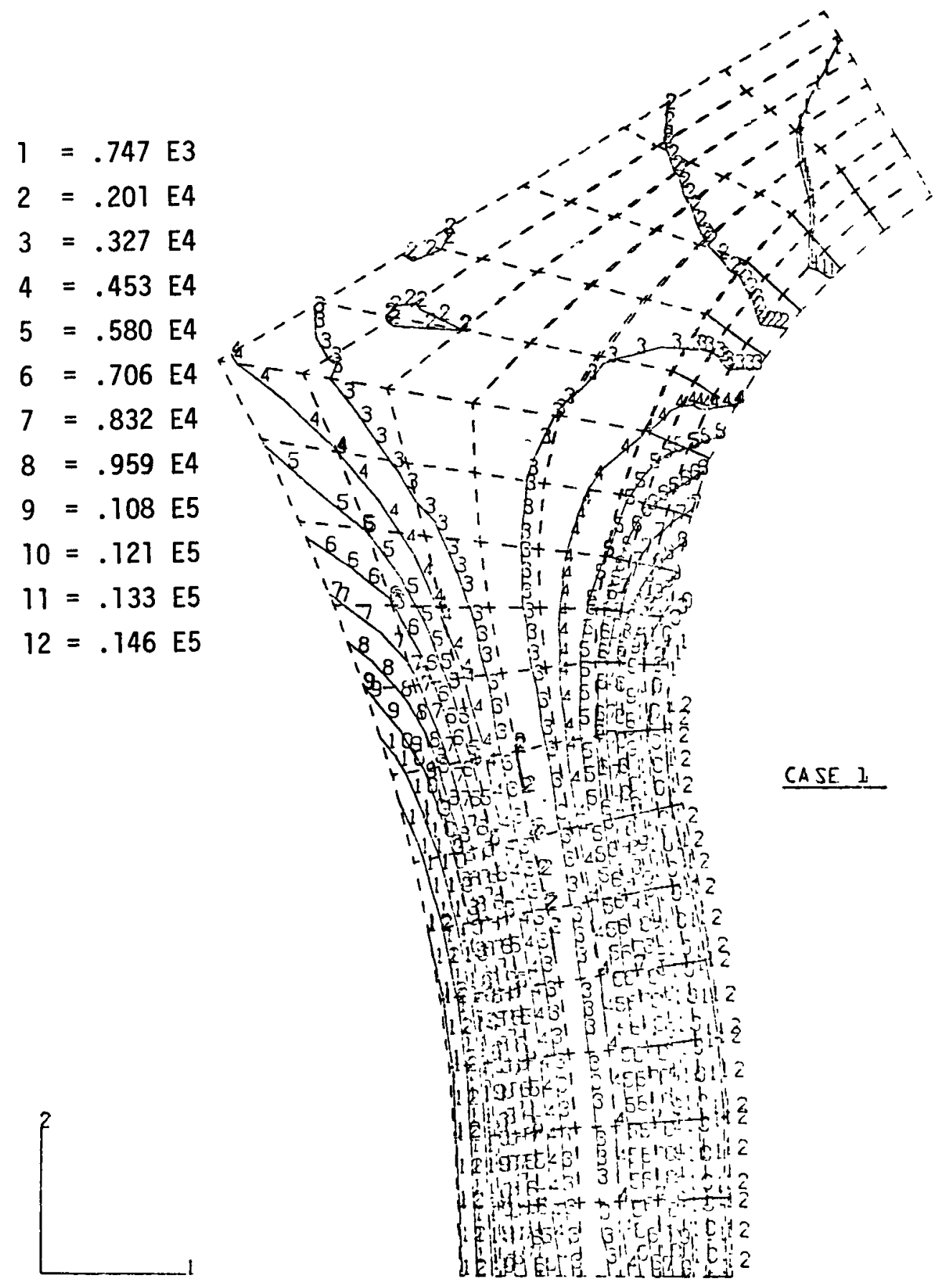

FIGURE 5. Effective Stress Contour Plots: Thermal Loads (Case 1: Axial Location $=8.25$ in.) 


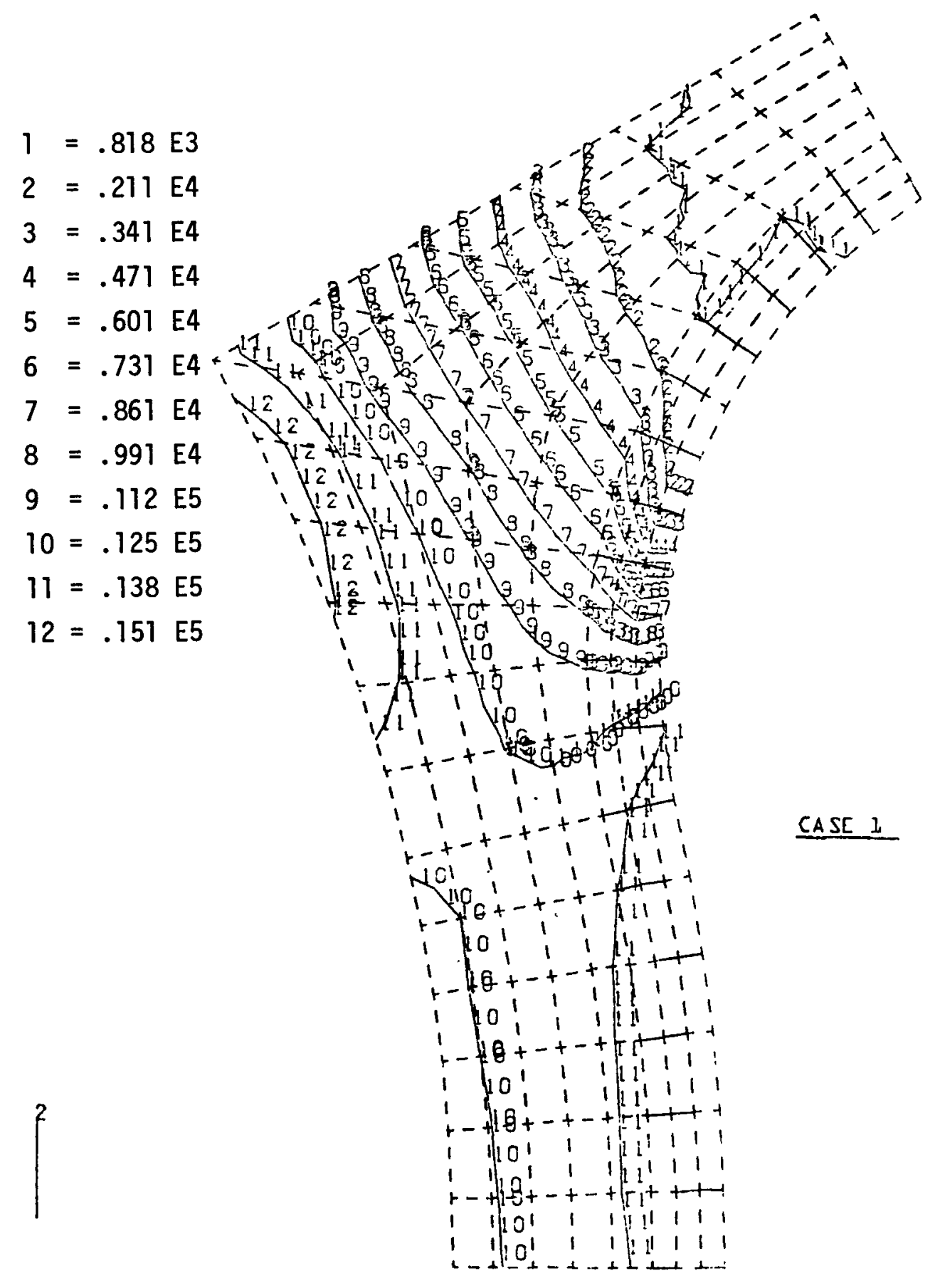

FIGURE 6. Effective Stress Contour Plots: Pressure Loads (Case 1: Axial Location $=8.25$ in.) 
On the basis of the elastic analysis, stress concentration effects associated with an integral fin cladding design were determined not to be major problems. Case 2 was selected as being the optimum design primarily on the basis of minimizing the temperature rise under the fin and from the standpoint of practicability of fabrication.

IneTastic analyses for the selected optimum fin design and reference cylindrical tube design were performed with the environmental conditions specified in Table VI. Tube 1 and integral fin cases $2 A$ and $2 B$ correspond to the top of an EBR-II fuel pin. Tube 2 and integral fin cases $2 C$ and 2D correspond to the mid-plane of an EBR-II fuel pin. Results of the inelastic analysis are summarized in Table IX. As can be seen, both the effective stress and total creep strain of the cylindrical tube are lower than that of the tube region of the integral fin design. Thus, it appears that the inelastic strains are tending to accumulate and higher stresses occur in the cylindrical region of the integral fin design. This indicates that the cylindrical portion of the integral fin cladding design is critical and has no definite structural advantage with respect to the conventional cylindrical tube design.

Comparison of integral fin cladding design $2 \mathrm{~A}$ with $2 \mathrm{~B}$ and $2 \mathrm{C}$ with $2 \mathrm{D}$ shows the effect of the reduction in fuel pin temperature achieved with the integral fin cladding design at two axial locations. At the higher temperatures there is only a small reduction in total creep strain and at the lower temperatures the strains are identical. Thus, the drop in fuel pin temperature achieved with the integral fin cladding design is offset by the strain concentrations resulting from the fin geometry. On this basis it is concluded that an integral fin design does not offer improved fuel pin performance with respect to the current reference wire wrap design.

C. Subassembly Duct Structural Analysis

Associated with the decrease in fuel pin temperature due to the integral fin cladding design is an increase in the duct wall temperature. This increase amounts to about $75^{\circ} \mathrm{F}$ for the 217 pin subassembly analyzed (Table III). To evaluate the effect of this temperature rise on duct performance, the 
TABLE IX

MAXIMUM EFFECTIVE STRESS AND MAXIMUM TOTAL CREEP STRAIN (CYLINDRICAL TUBE AND TUBE REGION OF CASE 2)

\begin{tabular}{|c|c|c|c|}
\hline \multicolumn{2}{|c|}{$\begin{array}{l}\text { Creep Analyses } \\
\text { Comparison }\end{array}$} & \multirow{2}{*}{$\frac{\begin{array}{c}\text { Max. Effective Stress } \\
(\text { ksi) }\end{array}}{21+}$} & \multirow{2}{*}{$\frac{\begin{array}{c}\text { Max. Total Creep } \\
\text { Strain }(\%)\end{array}}{0.42+}$} \\
\hline & Tube 1 & & \\
\hline & $2 B$ & $32++$ & $0.47++$ \\
\hline \multirow{2}{*}{2} & Tube 2 & 17 & 0.57 \\
\hline & $2 \mathrm{D}$ & 20 & 0.70 \\
\hline \multirow{2}{*}{3} & $2 A$ & 25 & 0.46 \\
\hline & $2 B$ & 23 & 0.47 \\
\hline \multirow{2}{*}{4} & $2 C$ & 20 & 0.70 \\
\hline & $2 D$ & 20 & 0.70 \\
\hline
\end{tabular}

+ Max. Effective Stress and Max. Total Creep Strain Occurred at the Outer Element of the Cylindrical Tube.

++ Max. Effective Stress and Max. Total Creep Strain Occurred at the Outer Elements of the Tube Region.

* Total Creep Strain = Irradiation Creep + Irradiation Swelling + Therma 1 Creep. 
computer code BEAMCRP ${ }^{(12)}$ was used to calculate the additional duct dilation. Duct-to-duct contact in the core region was selected as the limiting criteria. For purposes of evaluation, FFTF standard driver subassembly dimensions were utilized. Results of the analys is are summarized in Figure 7. The analysis assumes a $100 \mathrm{mil}$ radial duct dilation can be tolerated before duct touching occurs. Referring to Figure 7 , intersection of the creep dilation curves with the allowable creep dilation curves defines the lifetime limitation of the duct. As can be seen, the driver duct associated with the wire wrap design operating at $752^{\circ} \mathrm{F}$ is not lifetime limited out to three cycles burnup where a cycle is defined to be a full year operation at $75 \%$ availability. However, a comparable driver duct associated with an integral fin design would be lifetime limited to a burnup of approximately $130 \mathrm{MWd} / \mathrm{kg}$. Thus it appears that an integral fin spacer design would significantly limit duct performance.

IV. CONCLUSIONS AND RECOMMENDATIONS

An integral fin spacer concept is concluded to be inferior to the reference wire wrap design from the standpoint of fuel pin and duct performance. It is recommended that additional work not be conducted to develop this spacer concept.

An integral fin spacer design would effectively reduce coolant radial temperature gradients within an LMFBR subassembiy. The primary mechanism for redistributing the temperatures is redistribution of coolant flow by virtue of altering the subchannel flow areas rather than by improved coolant mixing induced by the spacer system. The effect is to reduce the peak cladding temperature and increase the duct wall temperature.

Increasing the number of pins in the subassembly decreases the integral fin effect on the peak cladding temperature while increasing the effect on duct wall temperature. Increasing the number of fins per fuel pin has an insignificant effect except on coolant pressure drop. A two fin design can potentially reduce the coolant pressure drop relative to that for a comparative wire wrap design. Varying the helical spacer pitch between 6 and 24 inches was found to have an insignificant effect on both temperature distribution and coolant pressure drop. 


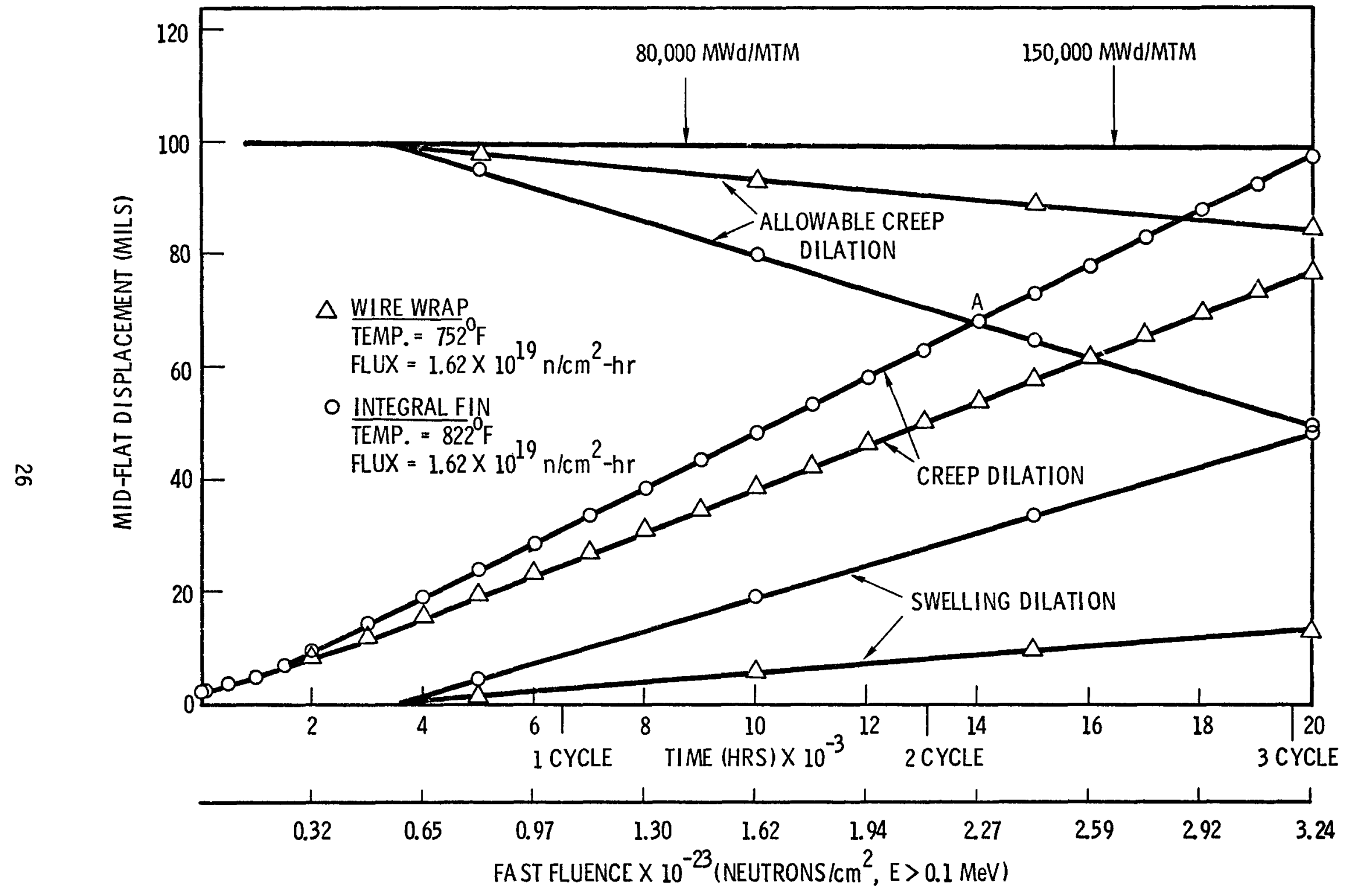

FIGURE 7. Typical Driver Duct Dilation. 
Cladding heat transfer calculations showed the temperature on the inside cladding diameter to peak directly under the fin. Reducing the fin width and fillet radius were found to minimize the temperature rise. However, the temperature rise is estimated to be comparable to that obtained with a wire wrap spacer design.

Concentration of elastic stresses associated with the fin geometry were found to be insignificant. However, inelastic strain concentrations were found to occur in the cylindrical region of the integral fin cladding design. This indicates the cylindrical portion away from the fin to be the critical region where failure would be most likely to occur.

Comparison of the predicted inelastic strains for the integral fin design with those for the cylindrical tube geometry, shows the strains to be greater for the fin design, even when taking into account the reduced cladding temperature. From the structural point of view, the reference cylindrical tube geometry is concluded to be superior to an integral fin design.

The increase in driver duct wall temperature associated with the integral fin design was found to significantly reduce predicted duct design lifetime. 


\section{REFERENCES}

1. Core Engineering Fiftieth Quarterly Report February-Apri1 1974, GEAP-10028-50, May 1974.

2. P. R. Pluta, W. G. Meinhardt, Design Basis of the F9E Grid Spaced LMFBR Diagnostic Assembly for Irradiation Test in EBR-II, GEAP-13765, December, 1971.

3. S. Kaplan, D. B. Atcheson, J. V. Marron, W. G. Meinhardt, Design Basis of the F9F Grid-Spaced FTR Diagnostic Assembly for Irradiation Tests in EBR-II, GEAP-13934, January, 1973.

4. Oxide Fuel Element Development Quarterly Progress Report for the Period Ending September 30, 1971, WARD-4270T3-10.

5. Oxide Fuel Element Development Quarterly Progress Report for the Period Ending September 30, 1973, WARD-0X-3045-4.

6. R. Krieg, Calculation of Stresses and Strains in Doubly Connected Prismatic Bodies with Sample Calculations for an Axially Finned Fuel Clad, Karlsruhe Nuclear Research Center, EURFNR-1048, October 1972.

7. H. Hoffman, Experimental Investigations on Coolant Cross Mixing and Pressure Drop in Rod Bundles with Helical Spacers Influence of the Results on the Design of Fuel Elements for Na-Cooled Fast Reactors, Karlsruhe Nuclear Research Center, BNWL-TR-117, December, 1973.

8. H. Hoffmann, K. Rust, Temperature and Stress Distributions in Fuel Rod Clads with Spiral Spacers for Steam-Cooled Fast Breeders, Karlsruhe Nuclear Research Center, EURFNR-607, June 1968.

9. W. Baumann, H. Hoffman, R. Moller, Fuel Rod Bundles with Various Spacer Designs for Sodium Cooled Fast Reactors, Karlsruhe Nuclear Research Center, IAEA-SM-130/38.

10. D. W. Rowe, COBRA III-C: A Digital Computer Program for Steady State and Transient Thermal-Hydraulic Analysis of Rod Bundle Nuclear Fuel Elements, BNWL-1695, March, 1973.

11. MARC Analysis Corporation, Control Data Corporation, MARC-CDC Non-Linear Finite Element Analysis Program, Vol. I, II, III, Publ. No. 17309500, 17311600, 17311700, Control Data Corporation, Minneapol is, Minn.

12. W. H. Sutherland, V. B.Watwood, Jr., Creep Analysis of Statically Indeterminate Beams, BNWL-1362, Battelle Northwest, Richland, Wa, June, 1970.

13. Liquid Metal Fast Breeder Reactor Materials Handbook, HEDL-TME 71-32. 